Data from deployment of temporary seismic stations in northern Norway and Finland

N. Maercklin, S. Mykkeltveit, J. Schweitzer, D. B. Harris, D. W. Rock

February 14, 2005 
This document was prepared as an account of work sponsored by an agency of the United States Government. Neither the United States Government nor the University of California nor any of their employees, makes any warranty, express or implied, or assumes any legal liability or responsibility for the accuracy, completeness, or usefulness of any information, apparatus, product, or process disclosed, or represents that its use would not infringe privately owned rights. Reference herein to any specific commercial product, process, or service by trade name, trademark, manufacturer, or otherwise, does not necessarily constitute or imply its endorsement, recommendation, or favoring by the United States Government or the University of California. The views and opinions of authors expressed herein do not necessarily state or reflect those of the United States Government or the University of California, and shall not be used for advertising or product endorsement purposes.

This work was performed under the auspices of the U.S. Department of Energy by University of California, Lawrence Livermore National Laboratory under Contract W-7405-Eng-48. 


\title{
6.4 Data from deployment of temporary seismic stations in northern Norway and Finland
}

\author{
Sponsored by National Nuclear Security Administration \\ Contract Nos. DE-FC52-01SF22420 (NORSAR) and W-7405-Eng-48 (LLNL)
}

\subsubsection{Introduction}

This short contribution is a description of data now available in NORSAR's data archives from a temporary deployment during 2002 - 2004 of six seismic stations in northern Norway and Finland.

Explosions in underground as well as open-pit mines in the Khibiny massif of the Kola Peninsula of northwestern Russia are conducted on a frequent and relatively regular basis. It was decided to supplement the network of permanent stations in northern Fennoscandia and northwest Russia with temporarily deployed stations, in order to record these explosions, as well as other mining explosions and natural events occuring in this general area. As shown in Fig. 6.4.1, the six temporary stations were deployed along two profile lines, extending westwards from the Khibini massif. The rationale for this deployment was to collect data to examine distance as well as azimuthal dependance of seismic discriminants. As can be seen from Fig. 6.4.1 the southernmost of the two profile lines runs through the permanent seismic array ARCES in northern Norway.

\subsubsection{Station equipment and locations}

Six RefTek 72A-08 data loggers (Refraction Technoloy) equipped with three-component GS13 seismometers (Teledyne Geotech) occupied positions along two profile lines during the time period from 27 August 2002 to 9 September 2004. Table 6.4.1 lists station names and coordinates. Two of the six stations, Ivalo (IVL) and Kaamasmukka (KMM), were located in northern Finland, and the remaining four were deployed in the Finnmark county of northern Norway. These were the sites Neiden (NDN), Skogfoss (SKF), Skoganvarre (SKV), and Varangerbotn (VGB). Fig. 6.4.2 shows a picture for the installation at VBG. During the deployment period of 745 days, a local representative of NORSAR visited the sites nine times to check the station status and to change the RefTek field disks. These were sometimes labeled with the alternative station codes GMM, SFS, and VRB instead of KMM, SKF, and VGB, respectively.

The seismometer coordinates at the stations NDN and VGB were determined directly with a GPS receiver, whereas the seismometer positions at the other stations were estimated from the corresponding data logger location using azimuth and distance to the seismometer. Each data logger location was taken as the median value of all (of the order of thousands) automatic GPS positionings done by the recorder during time corrections (see also the following section). Typically, the individual coordinates measured deviated less than about $20 \mathrm{~m}$ from the respective median value. Elevations for the stations in Norway were also verified with topographic maps in the scale 1:50000.

The natural frequency of the GS-13 seismometers is adjustable from $0.75 \mathrm{~Hz}$ to $1.1 \mathrm{~Hz}$ and was set to $1 \mathrm{~Hz}$ here. For calibration purposes Table 6.4.2 lists the coil generator constant of each sensor at each site, and Table 6.4.3 includes the calculated calibration constants (in $\mathrm{nm} /$ count) at $10 \mathrm{~Hz}$. The vertical component is denoted as $\mathrm{Z}$, and the horizontal components point to north (N) and east (E), respectively. 


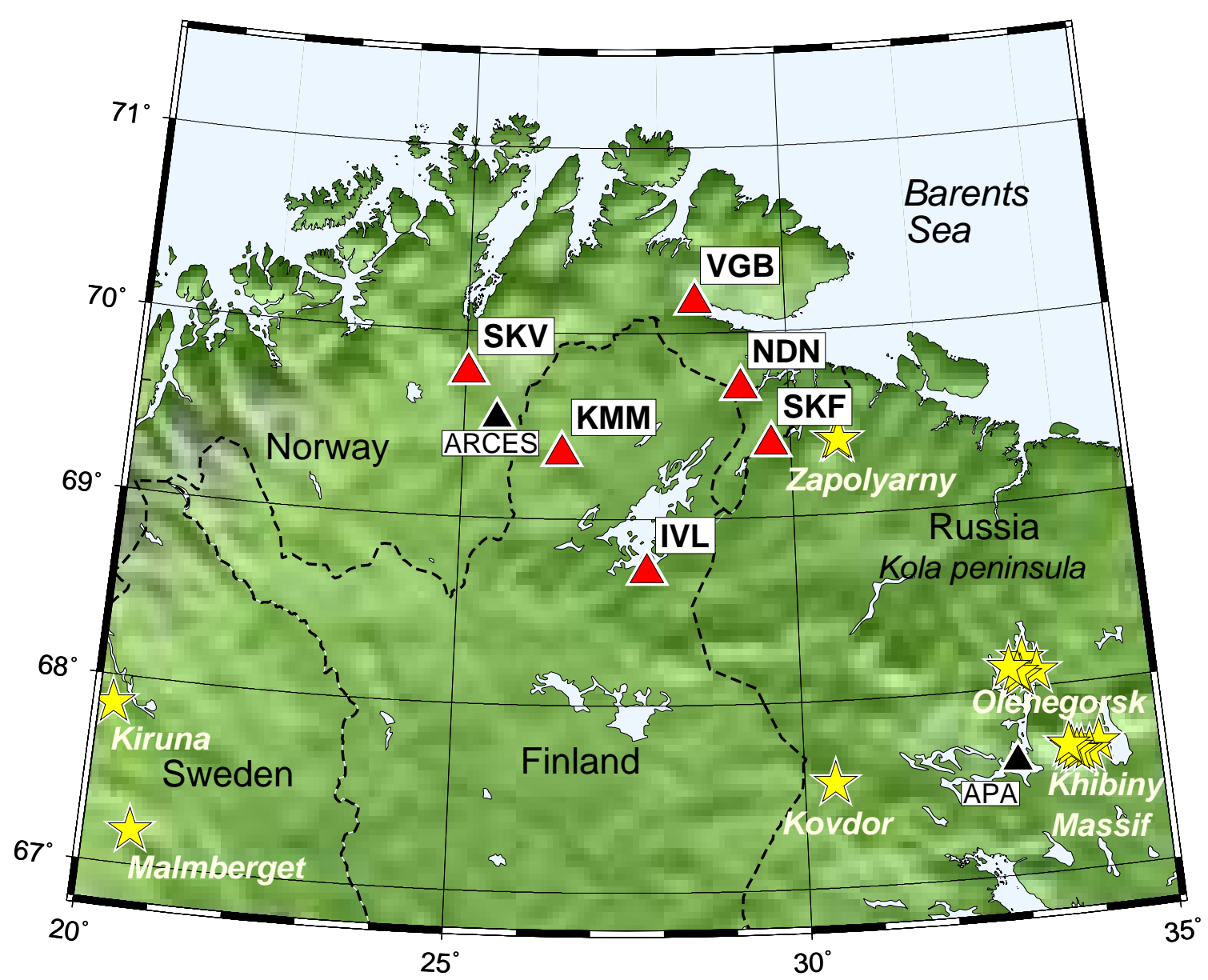

Fig. 6.4.1. Map of six temporary seismic stations (red triangles) in northern Norway and Finland, permanent seismic arrays (black triangles), and mining areas (yellow stars).

Table 6.4.1. Station names and locations

\begin{tabular}{|l|c|c|c|c|c|}
\hline \multicolumn{1}{|c|}{ Location } & Station & $\begin{array}{c}\text { Recorder } \\
\text { No. }\end{array}$ & Lat. N & Lon. E & $\begin{array}{c}\text { Elev. } \\
{[\mathbf{m}]}\end{array}$ \\
\hline \hline Ivalo & IVL & 689 & 68.71513 & 27.80159 & 120 \\
\hline Kaamasmukka & KMM & 853 & 69.34849 & 26.51432 & 220 \\
\hline Neiden & NDN & 856 & 69.69850 & 29.26333 & 90 \\
\hline Skogfoss & SKF & 686 & 69.39041 & 29.70506 & 60 \\
\hline Skoganvarre & SKV & 852 & 69.77436 & 25.04407 & 220 \\
\hline Varangerbotn & VGB & 855 & 70.16445 & 28.57550 & 6 \\
\hline
\end{tabular}




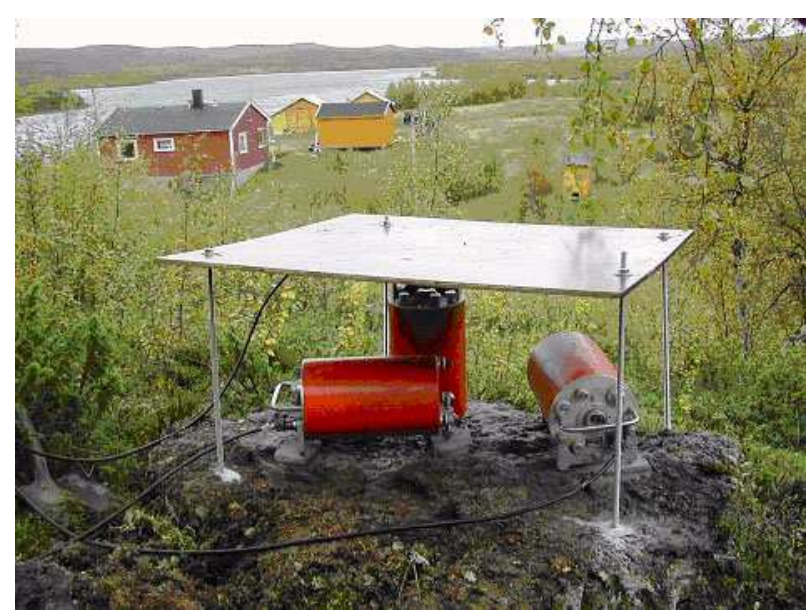

Fig. 6.4.2. This picture shows the seismometers at station Varangerbotn (VGB), before they were covered by soil, moss, and heather.

Table 6.4.2. Instrumentation (GS-13 sensors)

\begin{tabular}{|l|c|c|c|c|c|}
\hline Station & $\begin{array}{c}\text { Rec. } \\
\text { No }\end{array}$ & $\begin{array}{c}\text { Rec. } \\
\text { Chan. }\end{array}$ & Comp. & Sensor S/N & $\begin{array}{c}\text { Main coil generator } \\
\text { constant [Vs/m] }\end{array}$ \\
\hline \hline IVL & 689 & 4 & $\mathrm{Z}$ & 115 & 2130.4 \\
& & 5 & $\mathrm{~N}$ & 292 & 2366.0 \\
& & 6 & $\mathrm{E}$ & 294 & 2344.0 \\
\hline KMM & 853 & 4 & $\mathrm{Z}$ & 133 & 2311.4 \\
& & 5 & $\mathrm{~N}$ & 128 & 2305.6 \\
& & 6 & $\mathrm{E}$ & 283 & 2304.0 \\
\hline NDN & 856 & 4 & $\mathrm{Z}$ & 114 & 2118.9 \\
& & 5 & $\mathrm{~N}$ & 111 & 2130.0 \\
& & 6 & $\mathrm{E}$ & 113 & 2133.0 \\
\hline SKF & 686 & 4 & $\mathrm{Z}$ & 112 & 2159.8 \\
& & 5 & $\mathrm{~N}$ & 285 & 2369.0 \\
& & 6 & $\mathrm{E}$ & 288 & 2344.0 \\
\hline SKV & 852 & 4 & $\mathrm{Z}$ & 286 & 2343.0 \\
& & 5 & $\mathrm{~N}$ & 296 & 2335.0 \\
& & 6 & $\mathrm{E}$ & 297 & 2353.0 \\
\hline VGB & 855 & 4 & $\mathrm{Z}$ & 265 & 2339.0 \\
& & 5 & $\mathrm{~N}$ & 273 & 2323.0 \\
\hline & & 6 & $\mathrm{E}$ & 284 & \\
\hline
\end{tabular}




\subsubsection{Data recording}

The RefTek data loggers recorded digital data continously with a sampling rate of $100 \mathrm{~Hz}$ and with a dynamic range of 24 bits. In a testing phase during the first deployment days, the recorder's preamplifier gain was set to 32 at some stations, but was then adjusted to 1 for the remaining period. The adjustment times are given in Table 6.4.3 together with other acquisition parameters.

These digitized data (counts) were written in a native, compressed format (RefTek CO) to a hard disk attached to each data logger. The record length was 360054 samples, i.e. about 1 hour. The internal clock of each data logger was also adjusted nominally every hour using the time signal of the GPS satellites. All times are given in GMT.

Dump files of the recorder's hard disks were sent to NORSAR for subsequent data format conversion, quality control, and archiving. In a first step, the compressed data of all three components (channels) were expanded into a modified version of SEG-Y traces that can handle the long record length and keeps data logger specific information such as trace scaling. The recorder log files were also retrieved then. The logs include status information of the instruments, as well as time adjustments applied and its geographic location. In a second step, the SEG-Y traces were converted into the CSS3.0 format as one single file for each record (360054 samples) and the three components of each station. This format conversion was done mainly with the PASSCAL software package, and only the station name assignment utilized NORSAR's in-house EP program. These CSS data (more than $200 \mathrm{~GB}$ ) are delivered to Lawrence Livermore National Laboratory (LLNL), USA, to be included in their archive system. At NORSAR the final archive format is slightly different. Here, the data from all available stations were merged into single CSS3.0 files of exactly 1 hour length (360000 samples) and starting always at full hours. Additionally, calibration information was added (see also Table 6.4.3). This final format conversion step was also done with EP.

As shown in Fig. 6.4.3, data recording for the various stations ranged between about $38 \%$ and $89 \%$ of the entire deployment period. Table 6.4.4 and Fig. 6.4 .4 provide an overview of the days for which data are available. The stations with the longest uptime are IVL followed by VGB. Small data gaps at all stations are usually related to recorder maintanance (change of disk) or possible hard disk errors, i.e. bad blocks resulting in data decompression failure. The large gaps are caused by full disks, when a station could not be accessed in time for various reasons, or by failures of station power supply or recorder hardware. An example of the latter case is station SKF, which stopped operating already in the middle of 2003. Even though the average uptime must be rated as rather low, a high number of mining events were recorded during this two-year period, and this was the main objective of the deployment.

Except for the data gaps the data quality is generally good for seismic monitoring of events related to the mining activity on the Kola peninsula and for the analysis of teleseismic events. However, the initial quality control of the data revealed some scaling problems at the stations SKF and KMM during limited time periods in 2003. These scaling problems appear as anomalously high amplitudes of the recorded data and are most likely related to recorder hardware malfunction. At station SKF, this affected recordings of the vertical $(Z)$ component from 2003123:18.52.32 (after a data gap) until the station stopped operating at 2003-197:21.08.32. The data of station KMM show anomalously high amplitudes on all components starting at 2003205:13.36.56 and a more gradual amplitude decrease to the normal noise level at 2003- 
224:02.40.57. Besides that, data from the east (E) component of station NDN appear to be unusable for the entire recording period.

\subsubsection{Example of data recorded}

On 16 November 2002, one underground (total yield 257 tons for one ripple-fired explosion) and one open-pit explosion (total yield 430 tons for four separate ripple-fired explosions) were carried out in one of the mines in the Khibiny massif. The explosions were only $300 \mathrm{~m}$ apart, with the underground explosion occurring about 3 minutes before the open-pit explosion. These explosions were described in Ringdal et al. (2004), who noted a remarkable difference between the two sources in terms of spectral content: At lower frequencies, the underground explosion was stronger by a factor of 10 in amplitude, whereas the open-pit explosion was the stronger for high frequencies. Fig. 6.4.5 shows all data available from the temporary stations for these two explosions, for six different filter bands, ranging from $2-4 \mathrm{~Hz}$ in the upper left corner to $10-20 \mathrm{~Hz}$ in the lower right corner. In addition, data are shown for the central threecomponent station ARA0 of the ARCES array. The epicentral distances are $260 \mathrm{~km}$ for SKF, $279 \mathrm{~km}$ for IVL, $401 \mathrm{~km}$ for ARCES and $430 \mathrm{~km}$ for SKV. The spectral pattern found by Ringdal et al. (2004) for the station IVL is confirmed by all stations. Note that there is an interfering teleseismic signal (from an mb 5.4 event in the Kuriles) at about the time of the P-arrival for the underground explosion, most clearly seen for stations ARA0 and SKV in the lower passbands.

This work was performed, in part, under the auspices of the U.S. Department of Energy by University of California, Lawrence Livermore National Laboratory under Contract W-7405Eng-48.

\section{Reference}

Ringdal, F., T. Kværna, E. Kremenetskaya, V. Asming, S. Kozyrev, S. Mykkeltveit, S. J. Gibbons, and J. Schweitzer (2004). Research in regional seismic monitoring. Semiannual Technical Summary 1 January - 30 June 2004, NORSAR Sci. Rep. 2-2004, Kjeller, Norway.

\section{Nils Maercklin}

Svein Mykkeltveit

Johannes Schweitzer

Don Rock, Lawrence Livermore National Laboratory

David B. Harris, Lawrence Livermore National Laboratory 
Table 6.4.3. Data acquisition parameters and calibration constants

\begin{tabular}{|c|c|c|c|c|c|c|}
\hline Station & $\begin{array}{l}\text { Rec. } \\
\text { No. }\end{array}$ & $\begin{array}{c}\text { Rec. } \\
\text { Chan. } \\
\text { \& } \\
\text { Comp. }\end{array}$ & $\begin{array}{c}\text { Sample } \\
\text { rate } \\
{[\mathrm{Hz}]}\end{array}$ & $\begin{array}{l}\text { Pre- } \\
\text { amp. } \\
\text { gain }\end{array}$ & $\begin{array}{c}\text { Calibration } \\
\text { constant at } \\
10 \mathrm{~Hz} \\
{[\mathrm{~nm} / \text { count }]}\end{array}$ & Start time \\
\hline IVL & 689 & $\begin{array}{l}4, \mathrm{Z} \\
5, \mathrm{~N} \\
6, \mathrm{E} \\
4, \mathrm{Z} \\
5, \mathrm{~N} \\
6, \mathrm{E}\end{array}$ & $\begin{array}{l}100 \\
100\end{array}$ & $\begin{array}{r}32 \\
32 \\
32 \\
1 \\
1 \\
1\end{array}$ & $\begin{array}{l}0.0004444425 \\
0.0004001860 \\
0.0004030821 \\
0.0142221575 \\
0.0128059518 \\
0.0128986306\end{array}$ & $\begin{array}{l}\text { 2002-239:15.13.54 } \\
2002-244: 10.52 .50\end{array}$ \\
\hline KMM & 853 & $\begin{array}{l}4, \mathrm{Z} \\
5, \mathrm{~N} \\
6, \mathrm{E}\end{array}$ & 100 & $\begin{array}{l}1 \\
1 \\
1\end{array}$ & $\begin{array}{l}0.0131056206 \\
0.0131414299 \\
0.0131505564\end{array}$ & 2003-048:18.08.49 \\
\hline NDN & 856 & $\begin{array}{l}4, \mathrm{Z} \\
5, \mathrm{~N} \\
6, \mathrm{E} \\
4, \mathrm{Z} \\
5, \mathrm{~N} \\
6, \mathrm{E}\end{array}$ & $\begin{array}{l}100 \\
100\end{array}$ & $\begin{array}{r}32 \\
32 \\
32 \\
1 \\
1 \\
1\end{array}$ & $\begin{array}{l}0.0004468545 \\
0.0004445258 \\
0.0004439007 \\
0.0142993456 \\
0.0142248280 \\
0.0142048199\end{array}$ & $\begin{array}{l}\text { 2002-241:13.32.00 } \\
\text { 2002-243:08.20.01 }\end{array}$ \\
\hline SKF & 686 & $\begin{array}{l}4, \mathrm{Z} \\
5, \mathrm{~N} \\
6, \mathrm{E} \\
4, \mathrm{Z} \\
5, \mathrm{~N} \\
6, \mathrm{E} \\
4, \mathrm{Z} \\
5, \mathrm{~N} \\
6, \mathrm{E}\end{array}$ & $\begin{array}{l}100 \\
100 \\
100\end{array}$ & $\begin{array}{r}1 \\
1 \\
1 \\
32 \\
32 \\
32 \\
1 \\
1 \\
1\end{array}$ & $\begin{array}{l}0.0140285588 \\
0.0127897355 \\
0.0129261443 \\
0.0004383925 \\
0.0003996793 \\
0.0004039420 \\
0.0140285588 \\
0.0127897355 \\
0.0129261443\end{array}$ & $\begin{array}{l}\text { 2002-241:10.00.54 } \\
\text { 2002-242:13.31.29 } \\
\text { 2002-242: } 14.20 .32\end{array}$ \\
\hline SKV & 852 & $\begin{array}{l}4, \mathrm{Z} \\
5, \mathrm{~N} \\
6, \mathrm{E}\end{array}$ & 100 & $\begin{array}{l}1 \\
1 \\
1\end{array}$ & $\begin{array}{l}0.0129316621 \\
0.0129759666 \\
0.0128767031\end{array}$ & 2002-245:13.08.12 \\
\hline VGB & 855 & $\begin{array}{l}4, \mathrm{Z} \\
5, \mathrm{~N} \\
6, \mathrm{E} \\
4, \mathrm{Z} \\
5, \mathrm{~N} \\
6, \mathrm{E}\end{array}$ & 100 & $\begin{array}{r}32 \\
32 \\
32 \\
1 \\
1 \\
1\end{array}$ & $\begin{array}{l}0.0004051519 \\
0.0004048055 \\
0.0004075936 \\
0.0129648616 \\
0.0129537756 \\
0.0130429979\end{array}$ & $\begin{array}{l}2002-242: 10.29 .42 \\
2002-243: 10.45 .58\end{array}$ \\
\hline
\end{tabular}




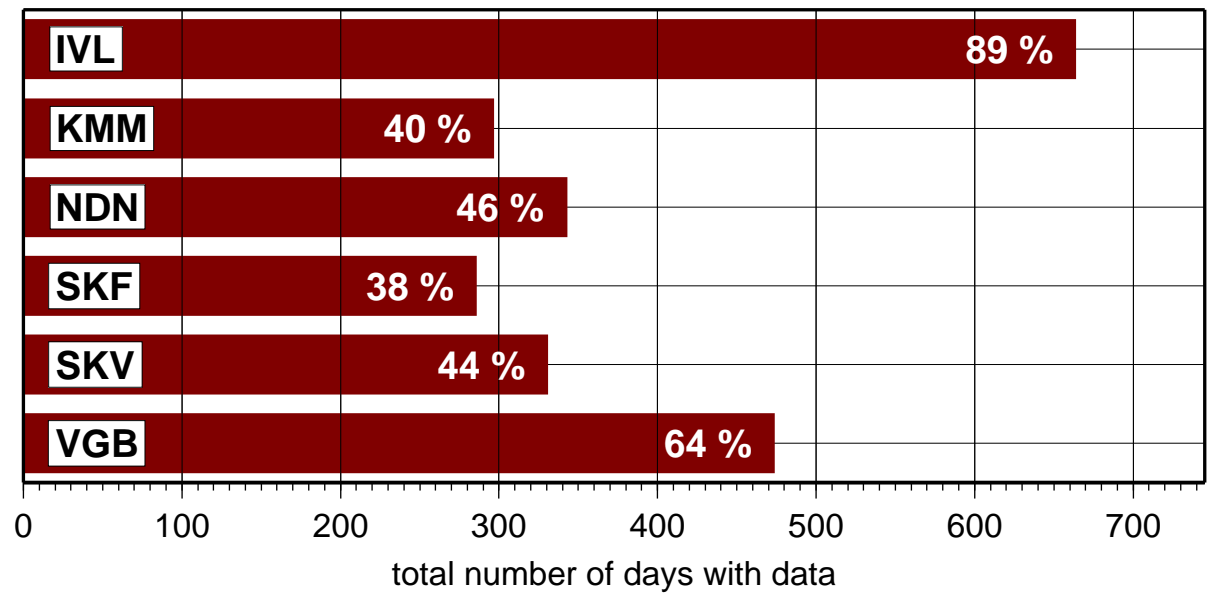

Fig. 6.4.3. Percentage of days of operation for each of the six temporary stations operating in northern Norway and Finland between 27 August 2002 and 9 September 2004. Continuous recording during the entire deployment period of 745 days corresponds to $100 \%$.

Table 6.4.4. Data availability

\begin{tabular}{|c|c|c|}
\hline Station & Year & Days of operation (Julian numbers) \\
\hline IVL & $\begin{array}{l}2002 \\
2003 \\
2004\end{array}$ & $\begin{array}{l}239-293,314-365 \\
001-017,044,049-173,176-177,180-220,223-233,236-317 \\
317-365 \\
001-039,040-115,140-253\end{array}$ \\
\hline KMM & $\begin{array}{l}2003 \\
2004\end{array}$ & $\begin{array}{l}048-157,176-224,274-282,316-365 \\
001-016,020,039-047,056,140-191\end{array}$ \\
\hline NDN & $\begin{array}{l}2002 \\
2003 \\
2004\end{array}$ & $\begin{array}{l}241-243 \\
097-161,164-240,340-352,355-357,360-365 \\
001-002,005-007,010-020,023-038,039-081,139-152,155-186, \\
189-191,194-196,199-208,211-217,220-247,250-252\end{array}$ \\
\hline SKF & $\begin{array}{l}2002 \\
2003\end{array}$ & $\begin{array}{l}241-245,248-320,323-365 \\
001-038,053-098,101-106,123-197\end{array}$ \\
\hline SKV & $\begin{array}{l}2002 \\
2003 \\
2004\end{array}$ & $\begin{array}{l}245-361 \\
061-066,069-176,241-266,297,315-365 \\
001-023\end{array}$ \\
\hline VGB & $\begin{array}{l}2002 \\
2003 \\
2004\end{array}$ & $\begin{array}{l}242-314 \\
097-098,100-164,177-244,248-316,340-365 \\
001-004,007-030,035-036,037-107,133-202\end{array}$ \\
\hline
\end{tabular}



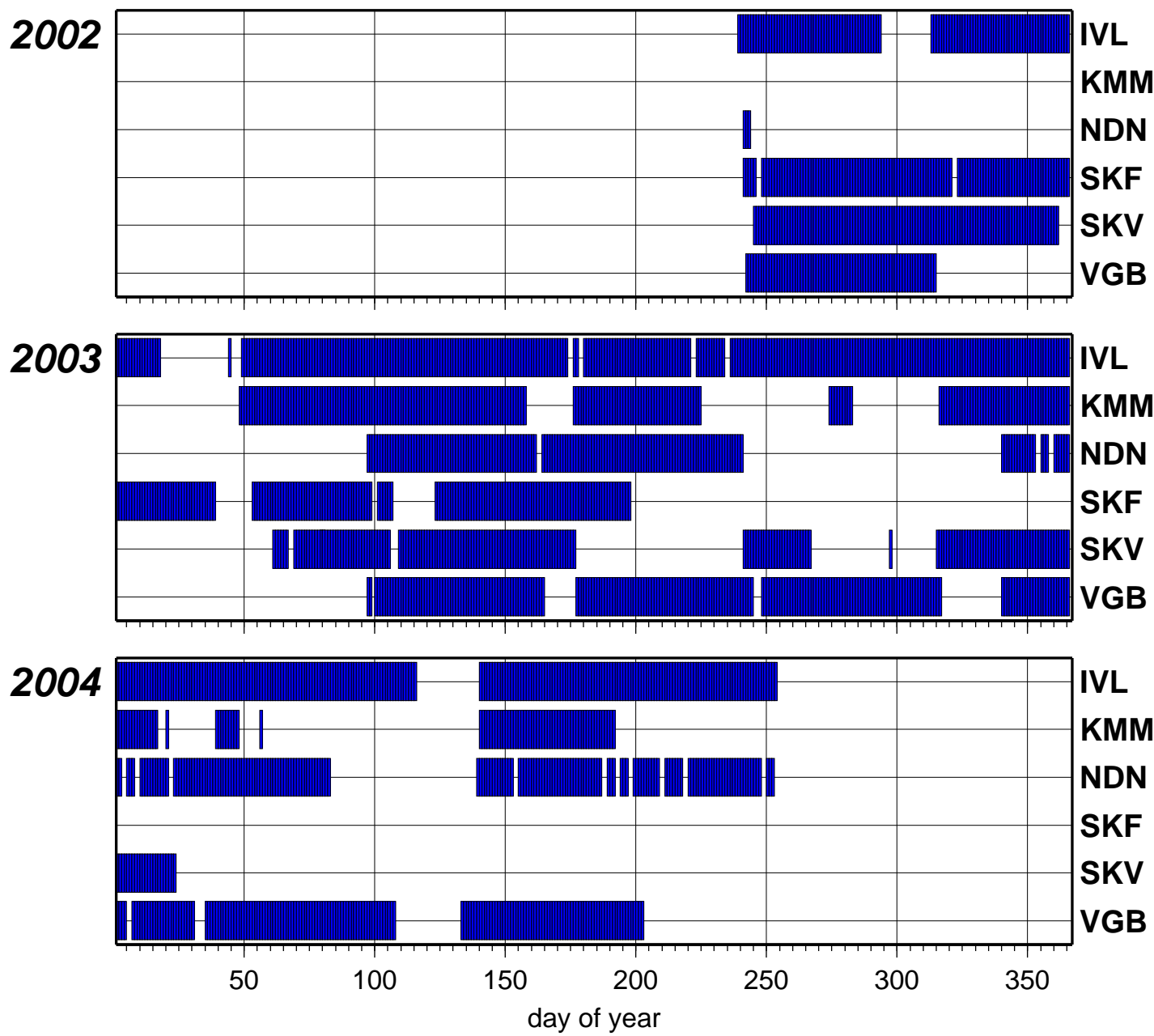

Fig. 6.4.4. Overview of days with data available from the six temporary stations operating in northern Norway and Finland between 27 August 2002 and 9 September 2004. The station locations are given in Fig. 6.4.1 and Table 6.4.1. 
2002-320:12.15.05 (2-4 Hz)

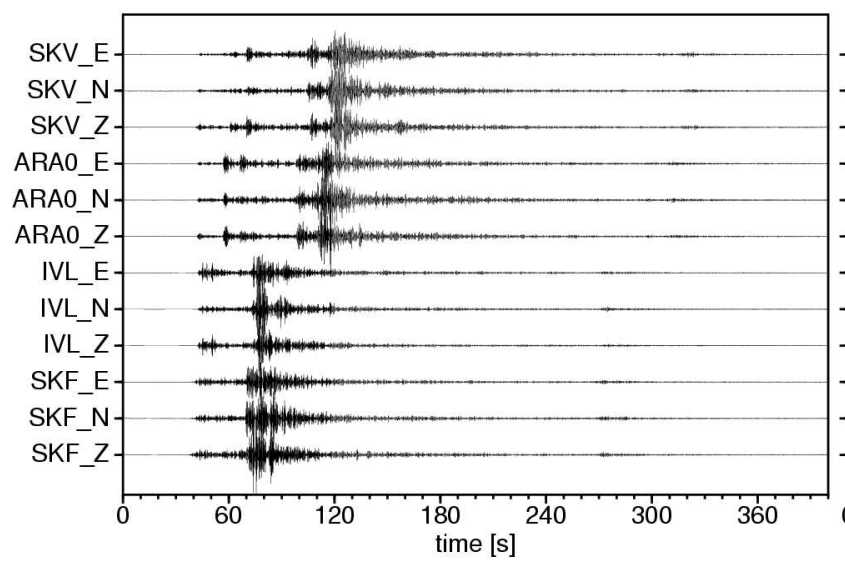

2002-320:12.15.05 (4-8 Hz)

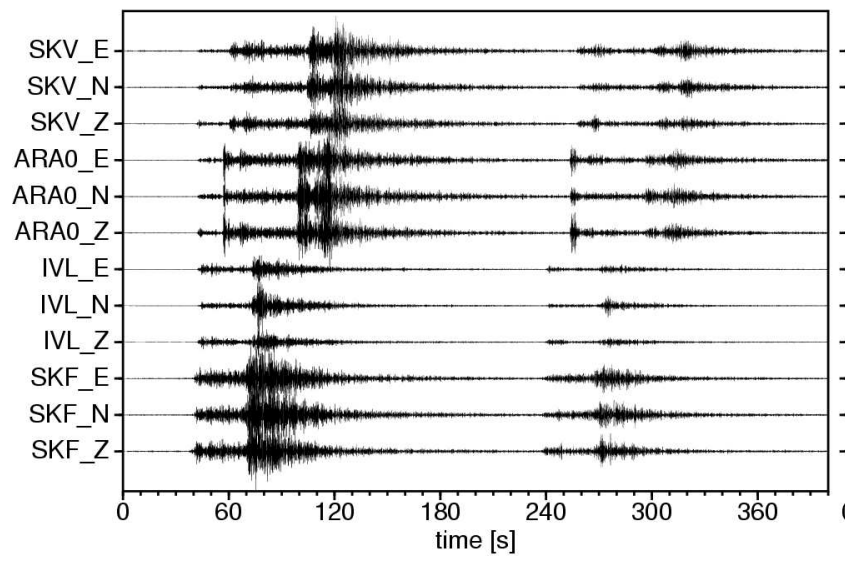

2002-320:12.15.05 (8-16 Hz)

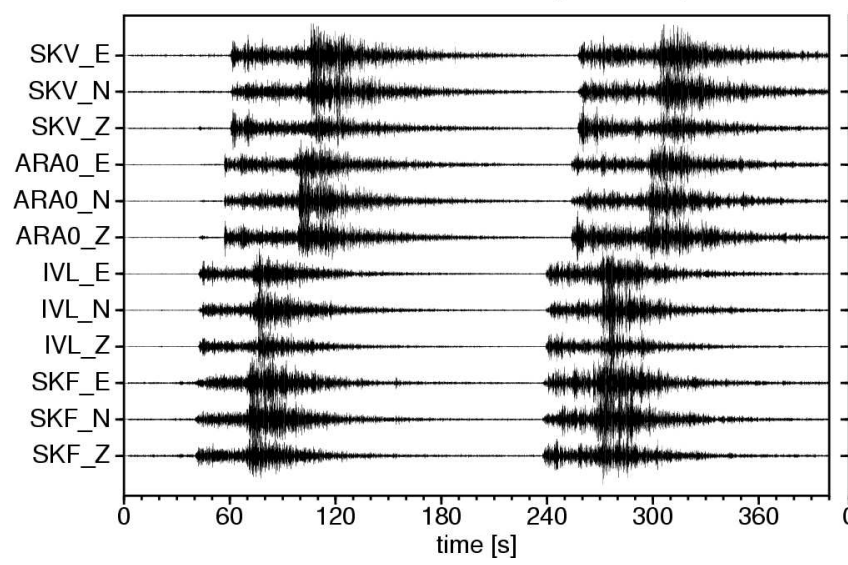

2002-320:12.15.05 (3-6 Hz)

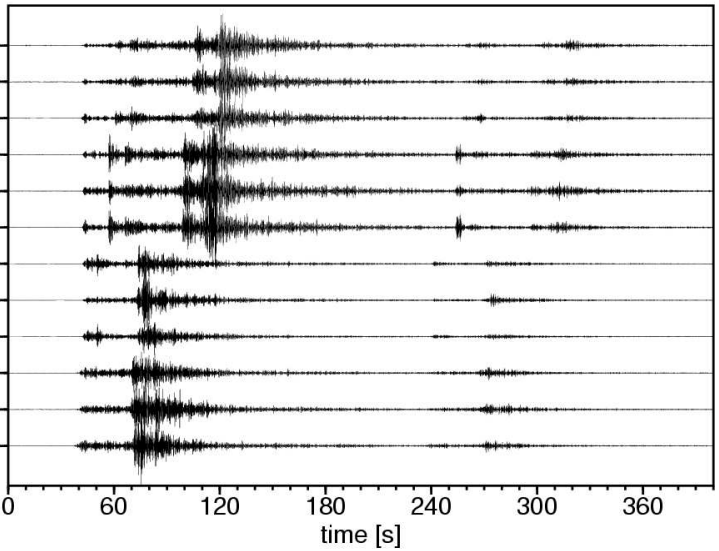

2002-320:12.15.05 (6-12 Hz)

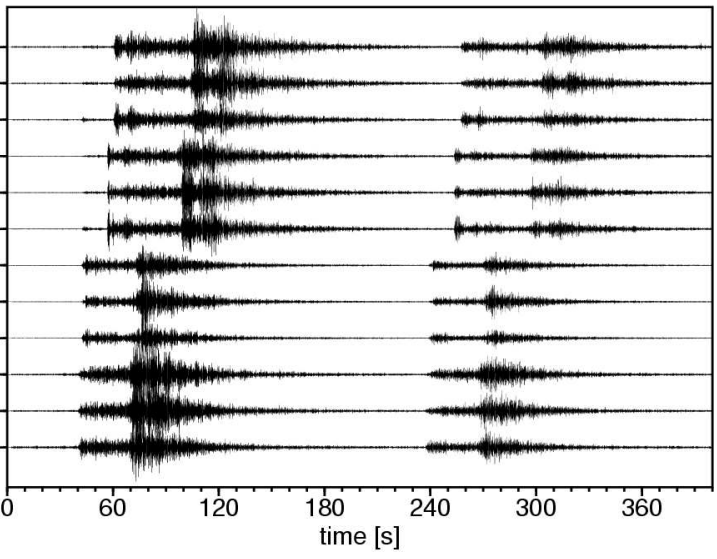

2002-320:12.15.05 (10-20 Hz)

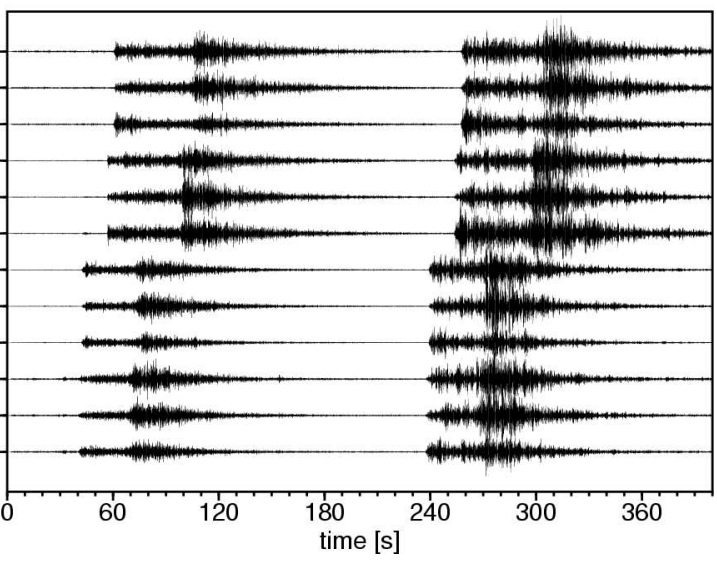

Fig. 6.4.5. The figure shows data from three of the temporary stations (SKF, IVL and SKV) as well as the three-component station ARAO of the ARCES array for two explosions in the Khibiny massif (see the text for details on the explosions). The data are filtered in six different frequency bands, as shown in the headers. All seismograms have been trace normalized, and the plot start time is the origin time of the first explosion, also given in the headers. 